\title{
PENGGUNAAN MEDIA AUDIO VISUAL TERHADAP TINGKAT PENGETAHUAN REMAJA TENTANG BAHAYA NAPZA
}

\author{
Ida Hayati ${ }^{1}$, Sumiati Sinaga ${ }^{2}$, Dini Nur Rahmayant ${ }^{3}$
}

Program Studi Diploma III Kebidanan STIKES Wiyata Husada Samarinda

email: idahayati@stikeswhs.ac.id

\section{ABSTRAK}

Latar Belakang: Remaja merupakan komponen yang penting dalam pembangunan nasional, sehingga diperlukan perhatian khusus. Masa remaja merupakan masa yang kritis yaitu masa saat berjuang melepaskan ketergantungan dari orang tua untuk mencapai kemandirian. Berdasarkan data dari Puslitdatin BNN (2018) dketahui bahwa di Kalimantan Timur, pada tahun 2017 tercatat 6.638 narapidana dan tahanan kasus narkoba yang berhasil ditangkap diketahui 5.804 orang pengedar narkoba dan 834 orang pengguna narkoba. Balai Rehabilitasi Narkoba Tanah Merah Kota Samarinda diketahui 207 orang penyalahguna narkoba dan 29 orang diantaranya adalah remaja. Tujuan: diketahuinya pengaruh penggunaan media audio visual terhadap tingkat pengetahuan remaja tentang bahaya NAPZA di SMP Negeri 9 Samarinda. Metode: Rancangan penelitian menggunakan preeksperimental dengan pendekatan one group pre-test dan post test design. Penelitian dilakukan bulan Februari-Agustus 2019. Populasi Penelitian siswa kelas VIII berjumlah 224 responden. Sampel berjumlah 30 responden diambil dengan menggunakan stratified random sampling. Hasil: Hasil uji paired t-test menunjukkan ada perbedaan nilai pengetahuan sebelum dan sesudah diberikan pendidikan kesehatan melalui audio visual dengan $p$ value $<0,05(0,0000)$, dimana nilai rerata sebelum diberikan 13,37 dan setelah diberikan meningkat menjadi 19,97 dengan nilai selisihnya 6.56. Simpulan: Penggunaan audio visual dalam pendidikan kesehatan dapat meningkatkan pengetahuan remaja tentang bahaya NAPZA di SMP Negeri 9 Samarinda.

\section{Kata Kunci: Audio visual, Pengetahuan, NAPZA, remaja.}

\section{PENDAHULUAN}

\section{Remaja merupakan komponen} penting dalam pembangunan nasional. Hal ini dikarenakan remaja yang akan meneruskan pembangunan dan cita-cita bangsa. Oleh karena itu perlu adanya perhatian khusus pada kelompok remaja ini. Masa remaja merupakan masa yang kritis, yaitu saat berjuang untuk melepaskan ketergantungan dari orang tua dan berusaha mencapai kemandirian. Keberhasilan remaja melalui masa transisi ini dipengaruhi oleh faktor individu dan lingkungan. Keinginan remaja cenderung melakukan jalan pintas dalam menghadapi masalah, tidak memiliki keyakinan diri yang mantap, menjadi pengikut yang tidak berdaya, mengelak dari tugas dan tanggung jawab dan hanya menuntut hak. Penyalahgunaan NAPZA adalah salah satu dari perilaku resiko tinggi pada remaja tersebut (BNN, 2004).

World Drugs Reports 2018 yang diterbitkan United Nations Office on Drugs

\footnotetext{
*Corresponding Author :

Ida Hayati

Program Studi D-III Kebidanan

ITKES Wiyata Husada Samarinda, Indonesia

Email : idahayati@stikeswhs.ac.id
} 
and Crime (UNODC), menyebutkan sebanyak 275 juta penduduk di dunia atau $5,6 \%$ dari penduduk dunia (usia 15-64 tahun) pernah mengonsumsi narkoba. Sementara di Indonesia, BNN selaku focal point di bidang Pencegahan dan Pemberantasan Penyalahgunaan dan Peredaran Gelap Narkoba (P4GN) mengantongi angka penyalahgunaan narkoba tahun 2017 sebanyak 3.376.115 orang pada rentang usia 10-59 tahun. Sedangkan angka penyalahgunaan Narkoba di kalangan pelajar di tahun 2018 (dari 13 ibukota provinsi di Indonesia ) mencapai angka 2,29 juta orang. Salah satu kelompok masyarakat yang rawan terpapar penyalahgunaan narkoba adalah mereka yang berada pada rentang usia 1535 tahun atau generasi milenial (BNN, 2019).

Di Kalimantan Timur, pada tahun 2017 berdasarkan data tercatat sebanyak 6.638 narapidana dan tahanan kasus narkoba berhasil ditangkap, rinciannya sebanyak 5.804 adalah pengedar narkoba dan pengguna narkoba sebanyak 834 orang. Sedangkan di Balai Rehabilitasi Narkoba Tanah Merah Kota Samarinda Propinsi Kalimantan Timur, terdapat 207 orang penyalahguna narkoba. Dari jumlah tersebut sebanyak 29 orang penyalahguna adalah remaja (BNN, 2018).

\section{*Corresponding Author :}

Ida Hayati

Program Studi D-III Kebidanan

ITKES Wiyata Husada Samarinda, Indonesia

Email : idahayati@stikeswhs.ac.id
Studi pendahuluan yang dilakukan pada tanggal 11 Maret 2019 dengan melakukan wawancara 5 orang siswa/i, didapatkan hasil bahwa 2 orang cukup memahami tentang bahaya NAPZA dan 3 orang masih kurang pemahamannya terhadap NAPZA, karena hanya tahu sebatas sampai narkoba saja dan tidak memahami dampak lebih dari narkoba. Informasi yang disampaikan oleh guru BK (Bimbingan Konseling) kelas VIII SMP Negeri 9 Samarinda, belum ada siswa di sekolah yang tertangkap karena penyalahgunaan narkoba, akan tetapi pernah ada satu orang siswa di kelas VIII yang tertangkap membawa zat adiktif yaitu rokok. Sebagian besar dari mereka tidak mengetahui bahwa rokok sendiri termasuk dalam golongan zat adiktif yang dapat menjadi pintu masuk terjadinya penyalahgunaan NAPZA yang berbahaya bagi kesehatan tubuh.

Pendidikan kesehatan adalah suatu upaya atau kegiatan untuk menciptakan perilaku masyarakat yang kondusif untuk kesehatan. Artinya pendidikan kesehatan berupaya agar masyarakat menyadari atau mengerti atau mencegah hal-hal yang merugikan kesehatan mereka, dan kesehatan orang lain (Notoatmodjo, 2003). Pendidikan kesehatan merupakan salah satu metode untuk mencegah penyalahgunaan NAPZA yang mempunyai 
peranan penting dalam memberikan pengetahuan kepada remaja tentang NAPZA. Dalam pemberian pendidikan dan promosi kesehatan, diperlukan adanya media atau alat bantu dalam memudahkan penyampaian materi yang akan disampaikan kepada audiens. Alat bantu pendidikan adalah alat-alat yang digunakan oleh pendidik dalam menyampaikan bahan pendidikan. Alat bantu ini sering disebut dengan alat peraga karena berfungsi memperagakan sesuatu di dalam proses pendidikan (Notoatmodjo, 2007). Penggunaan audio visual pada penelitian ini dikarenakan alat bantu ini mempunyai banyak manfaat yang sangat membantu dalam memberikan informasi kepada siswa, dapat membantu siswa dalam memahami sebuah materi atau ilmu, siswa akan lebih berkonsentrasi dan berimplikasi pada pemahaman mereka sendiri karena alat pendengaran dan penglihatan digunakan secara bersamaan sehingga membutuhkan konsentrasi yang besar. Pemutaran video tentang pendidikan kesehatan yang berisi gambar gerak dan suara akan lebih mudah diingat.

Tingginya perilaku beresiko pada remaja yang ditunjukkan dalam data-data di atas merupakan hasil dari sifat khas remaja, pengetahuan remaja tentang kesehatan, nilai moral yang dianut serta ada tidaknya kondisi lingkungan yang

\section{*Corresponding Author :}

Ida Hayati

Program Studi D-III Kebidanan

ITKES Wiyata Husada Samarinda, Indonesia

Email : idahayati@stikeswhs.ac.id kondusif. Remaja yang tidak bisa mengatasi berbagai stressor yang ada akan menimbulkan berbagai kondisi yang negatif, sehingga dapat memicu munculnya gangguan psikotik. Untuk itu diperlukan bekal bagi remaja dengan informasi yang tepat. Berdasarkan uraian masalah tersebut maka peneliti akan meneliti penggunaan audio visual terhadap pengetahuan remaja tentang bahaya NAPZA di SMP Negeri 9 Samarinda.

\section{METODE PENELITIAN}

Penelitian ini merupakan penelitian kuantitatif. Rancangan penelitian ini menggunakan pre-eksperimental dengan rancangan one group pre-test dan post-test desaign yaitu sebelum diberikan pendidikan kesehatan bahaya NAPZA dilakukan pre-test, kemudian setelah diberikan pendidikan kesehatan bahaya NAPZA dilakukan pengukuran lagi dengan cara post-test untuk mengetahui pengetahuan responden.

\section{HASIL PENELITIAN DAN PEMBAHASAN}

\section{HASIL PENELITIAN}

\section{Karakteristik Responden}

Responden yang terlibat dalam penelitian ini adalah responden yang sesuai dengan jumlah sampel yang ditentukan oleh peneliti, jumlah sampel 
yang ditentukan oleh peneliti yaitu 30 orang. Data responden yang diperoleh dari penelitian ini antara lain karakteristik umur, dan jenis kelamin. Karakteristik berdasarkan umur responden yang diperoleh peneliti selanjutnya dikelompokkan menjadi umur 13 dan 14 tahun, diketahui bahwa dari 30 responden terdapat 23 berumumur 13 tahun $(76,7 \%)$ dan 7 responden berumur 14 tahun $(23,3 \%)$

Karakteristik berdasarkan jenis kelamin responden yang diperoleh peneliti selanjutnya dikelompokkan menjadi 2 kelompok yaitu laki-laki dan perempuan, bahwa distribusi jenis kelamin dari 30 responden yang paling banyak adalah kelompok jenis kelamin perempuan, yaitu sebanyak 20 orang $(66,7 \%)$.

Dalam penelitian ini terdapat dua variabel yaitu Penggunaan media audio visual dan pengetahuan remaja tentang bahaya NAPZA, diketahui bahwa rata-rata nilai sebelum diberikan pendidikan kesehatan sebelum dan sesudahnya. Nilai pada pre-test nilai mean 13,37 dengan standar deviasi 1,89 maksimal 16 dan minimum 9 sedangkan nilai pada post-test nilai mean 19,93 dengan standar deviasi 1,856, maksimal 24 minimum 17 dengan tingkat kepercayaan 95\% dari hasil uji statistik terdapat perbedaan nilai.

\section{*Corresponding Author:}

Ida Hayati

Program Studi D-III Kebidanan

ITKES Wiyata Husada Samarinda, Indonesia

Email : idahayati@stikeswhs.ac.id

\section{Perhitungan Effect Size}

Effect size merupakan sebuah metode yang dilakukan untuk mengetahui besar keefektifan, istilah lainnya bisa di artikan sebagai langkah untuk mengukur seberapa besar skala keefektifan metode/model yang telah kita uji dan terapkan. Effect size dalam statistik digunakan untuk menentukan besarnya skala keefektifan sebuah penelitian. Berdasarkan hasil penelitian diketahui bahwa semua responden yang berjumlah 30 dilakukan pengukuran pengetahuan terlebih dahulu sebelum dilakukan intervensi pendidikan kesehatan dengan media audio visual terhadap tingkat pengetahuan bahaya NAPZA, lalu diberikan pendidikan kesehatan sebanyak satu kali. Setelah dilakukan analisis dengan menggunakan uji paired t-test, didapatkan ada perbedaan nilai pengetahuan sebelum dan sesudah diberikan pendidikan kesehatan pada siswa kelas VIII dengan $p$ value $<0,05(0,000)$, sehingga dapat dikatakan bahwa penggunaan media audio visual dapat meningkatkan pengetahuan bahaya NAPZA di kelas VIII SMP Negeri 9 Samarinda.

\section{Pengetahuan Remaja di SMP Negeri 9} Samarinda sebelum diberikan pendidikan kesehatan dengan media audio visual 
Hasil penelitian menunjukkan bahwa sebelum diberikan pendidikan kesehatan responden didapatkan nilai rerata sebelum diberikan pendidikan kesehatan bahaya NAPZA adalah 13,37 dengan nilai minimum 9 dan maksimum 16 . Berdasarkan nilai rerata tersebut, dapat diketahui bahwa pengetahuan responden sebelum diberikan pendidikan kesehatan cenderung ke arah baik, dimana masih ada beberapa komponen tentang NAPZA yang belum diketahui oleh responden. Hal ini dapat dilihat dari distribusi jawaban responden dari 3 item pernyataan yang menunjukan bahwa sebagian responden belum mengetahui tentang bahaya dan dampak yang ditimbulkan, hal ini dikarenakan pengetahuan yang selama ini responden dapatkan seputar NAPZA hanya sampai pada pengertian dan jenis-jenis NAPZA saja, sedangkan pada item pernyataan mengenai faktor penyalahgunaan NAPZA, rata-rata responden memiliki skor yang tinggi. Berdasarkan informasi yang didapatkan dari kuesioner, rata-rata responden mendapatkan pengetahuan tentang faktor penyalahgunaan NAPZA melalui informasi dari berbagai sumber maupun lingkungan sekitarnya yaitu dari teman sebaya, saudara, maupun informasi dari media elektronik atau cetak yang didapatkan oleh responden.

\section{*Corresponding Author :}

Ida Hayati

Program Studi D-III Kebidanan

ITKES Wiyata Husada Samarinda, Indonesia

Email : idahayati@stikeswhs.ac.id
Pengkajian tingkat pengetahuan remaja sebelum diberikan pendidikan kesehatan ini sangat berguna untuk menentukan materi apa yang perlu diberikan secara mendalam kepada responden sehingga dapat menambah pengetahuan responden yang masih kurang. Menurut Effendy (2009), langkah yang harus ditempuh dalam melakukan pendidikan kesehatan yaitu, mengkaji kebutuhan masyarakat, menetapkan masalah kesehatan masyarakat, memprioritaskan masalah yang selanjutnya ditangani melalui pendidikan kesehatan dengan menggunakan media yang tepat.

\section{Pengetahuan Remaja di SMP Negeri 9} Samarinda setelah diberikan pendidikan kesehatan dengan media audio visual

$$
\text { Hasil penelitian menunjukkan }
$$
bahwa sesudah diberikan pendidikan kesehatan menggunakan media audio visual terhadap tingkat pengetahuan bahaya NAPZA berdasarkan nilai rerata tersebut meningkat dari skor sebelum diberikan pendidikan kesehatan dengan nilai rerata sesudah sebanyak 19,93 dengan nilai minimum 17 dan nilai maksimum 24. Berdasarkan distribusi jawaban yang didapatkan, responden mengalami peningkatan pengetahuan sesudah diberikan pendidikan kesehatan hampir pada semua aspek pertanyaan. Dengan 
pernyataan yang terdapat didalam kuisioner, rata-rata responden sudah memiliki pengetahuan yang baik pada semua aspek pertanyaan.

$$
\text { Hasil penelitian menunjukkan }
$$

bahwa pengetahuan responden tentang bahaya napza meningkat setelah diberikan pendidikan kesehatan. Hal ini sejalan dengan Notoatmodjo (2010), menjelaskan bahwa secara operasional pendidikan kesehatan merupakan kegiatan untuk memberikan atau meningkatkan pengetahuan, sikap dan praktik baik individu, kelompok atau masyarakat dalam memelihara dan meningkatkan kesehatan mereka sendiri. Senada dengan penelitian Hanif dan Isnaeni (2017), yang menjelaskan bahwa pengetahuan responden dapat memberikan dasar pembentukan sikap serta informasi tentang pencegahan penyalahgunaan narkoba yang diberikan oleh peneliti melalui audio visual.

\section{Pengaruh Penggunaan Media audio visual terhadap tingkat pengetahuan remaja di SMP Negeri 9 Samarinda}

Pada penelitian ini, rata-rata responden menunjukkan peningkatan skor pengetahuan setelah diberikan pendidikan kesehatan menggunakan media audio visual, dengan perbedaan reratanya adalah 6,56. Notoatmodjo (2012) menjelaskan pengetahuan sebagai hasil tahu, setelah seseorang melakukan penginderaan terhadap objek tertentu melalui indera penglihatan dan pendengaran. Pengetahuan merupakan faktor yang sangat penting untuk terbentuknya tindakan dan informasi yang didapat seseorang, karena perilaku yang didasari oleh pengetahuan akan langgeng daripada perilaku yang tidak didasari oleh pengetahuan. Pengetahuan itu sendiri dipengaruhi oleh beberapa faktor, karena responden yang di ambil memiliki tingkat pengetahuan formal yang sama. Menurut teori WHO yang dikutip oleh Notoatmodjo (2007), salah satu bentuk objek kesehatan dapat dijabarkan oleh pengetahuan yang diperoleh dari pengalaman sendiri, maka perbedaan pengetahuan setiap siswa/i bisa dikarenakan informasi di luar pendidikan non formal yang didapat siswa/i secara individu seperti media massa, media elektronik, dan infomasi dari internet. Pengetahuan seseorang tentang suatu objek mengandung dua aspek ini yang akan menentukan sikap seseorang, semakin banyak aspek positif dan objek yang diketahuinya, maka akan menimbulkan sikap makin positif terhadap objek tertentu.

$$
\text { Penelitian Setiyaji }
$$

menunjukkan bahwa ada pengaruh

\section{*Corresponding Author :}

Ida Hayati

Program Studi D-III Kebidanan

ITKES Wiyata Husada Samarinda, Indonesia

Email : idahayati@stikeswhs.ac.id 
pendidikan kesehatan melalui media video terhadap pengetahuan bahaya NAPZA pada remaja kelas $X$ di Yogyakarta, dimana sebelum diberikan pendidikan kesehatan ada 33 responden yang pengetahuannya maksimal dan setelah diberikan pendidikan kesehatan meningkat menjadi 49 orang. Dalam penelitian ini dijelaskan bahwa faktor-faktor yang dapat mempengaruhi pengetahuan respondennya adalah teman sebaya, dan rasa ingin tahu yang tinggi terhadap masalah yang sedang populer seperti NAPZA, dimana pada usia remaja seseorang mampu dengan cepat memahami informasi yang diterimanya.

\section{SIMPULAN}

Pendidikan kesehatan menggunakan media audio visual dapat meningkatkan pengetahuan bahaya NAPZA pada remaja kelas VIII di SMP Negeri 9 Samarinda, hasil penelitian menunjukkan ada perbedaan nilai pengetahuan sebelum dan sesudah diberikan pendidikan kesehatan pada siswa kelas VIIldengan $p$ value $<0,05 \quad(0,000)$, dimana nilai rerata sebelum diberikan 13,37 dan setelah diberikan meningkat menjadi 19,97 dengan nilai selisihnya 6,56,

\section{SARAN}

\section{*Corresponding Author:}

Ida Hayati

Program Studi D-III Kebidanan

ITKES Wiyata Husada Samarinda, Indonesia

Email : idahayati@stikeswhs.ac.id
Penelitian ini dapat berdayaguna sebagai bahan referensi bagi mahasiswa yang lain serta memberikan tambahan karya tulis ilmiah. Hasil penelitian ini dapat menjadi pertimbangan untuk penerapan penggunaan audio visual terhadap tingkat pengetahuan remaja mengenai bahaya konsumsi Napza.

\section{DAFTAR PUSTAKA}

Aminah. 2018. Pengaruh Pendidikan Kesehatan Melalui Audio Visual Terhadap Pengetahuan Tentang Penyalahgunaan Narkoba pada Remaja Kelas VII SMPN 1 Bangsal. Online:

http://hdl.handle.net/123456789/206

BNN. 2004. Buku Pedoman Praktis Mengenai Penyalahgunaan NAPZA Bagi Petugas. BNN. Jakarta

BNN. 2011. Survei Nasional Perkembangan Penyalahgunaan Narkoba. BNN. Jakarta

BNN. 2018. Indonesia: Narkoba Dalam Angka Tahun 2017. Jurnal Data Puslitdatin BNN. Jakarta

BNN. 2019. Penggunaan Narkotika di Kalangan Remaja Meningkat. Online: https://bnn.go.id/penggunaannarkotika-kalangan-remajameningkat/

Fitriani.S. (2011). Promosi Kesehatan. Ed 1. Yogyakarta: Graha IImu 
Jurnal Medika Karya IImiah Kesehatan

Vol 5, No.1. 2020

ISSN : 2654-945X (Online), 2541-4615 (Print)

Journal homepage : http://jurnal.itkeswhs.ac.id/index.php/medika

Hanif, M. dan Isnaeni, Y. 2017. Pengaruh

Pendidikan Ksehtan Melalui Audio

Visual terhadap Sikap Pencegahan

Penyalahgunaan Narkoba Pada

Remaja Kelas VIII di SMP Ma'arif

Gamping Yogyakarta. Online:

http://digilib.unisayogya.ac.id/2462/1

LMIFTAHUL\%2OHANIF\%20\%28201510

104437\%29\%20NASKAH\%2OPUBLIKASI

. ddf

Notoatmodjo, S. 2007. Promosi Kesehatan dan IImu Perilaku. Rineka Cipta. Jakarta.

Notoatmodjo, S. 2010. Metodologi Penelitian Kesehatan. Rineka Cipta. Jakarta

Notoatmodjo, S. 2003. Pendidikan dan Perilaku Kesehatan. Rineka Cipta. Jakarta

Setiyaji et al. 2017. Pengaruh Pendidikan Kesehatan Melalui Media Video Terhadap Pengetahuan Bahaya NAPZA Pada Remaja Kelas X MAN Maguwoharjo. Yogyakarta.

World Health Organization. 2012. Report of The International Narcotics Control Board for 2012.

Yunitasari (2018) Hubungan Dukungan Keluarga Dan Self Efficacy Dengan Upaya Pencegahan Relapse Pada Penyalahguna NAPZA Pasca Rehabilitaasi di Badan Narkotika Nasional Provinsi Kalimantan Timur

\section{*Corresponding Author :}

Ida Hayati

Program Studi D-III Kebidanan

ITKES Wiyata Husada Samarinda, Indonesia

Email : idahayati@stikeswhs.ac.id 